\title{
Agronomical, biochemical and histological response of resistant and susceptible wheat and barley under BYDV stress
}

\author{
Shormin Choudhury ${ }^{1,2}$, Hongliang Hu ${ }^{1}$, Philip Larkin ${ }^{3}$, Holger Meinke ${ }^{1,4}$, Sergey Shabala ${ }^{4}$, Ibrahim \\ Ahmed ${ }^{1}$, Meixue Zhou ${ }^{\text {Corresp. } 1}$ \\ 1 Tasmanian Institute of Agriculture, University of Tasmania, Prospect, Tasmania, Australia \\ 2 Department of Horticulture, Faculty of Agriculture, Sher-e-Bangla Agricultural University, Sher-e-Bangla Nagar, Dhaka, Bangladesh \\ 3 CSIRO Agriculture and Food, Canberra, Australia \\ 4 Tasmanian Institute of Agriculture, University of Tasmania, Hobart, Tasmania, Australia \\ Corresponding Author: Meixue Zhou \\ Email address: mzhou@utas.edu.au
}

Barley yellow dwarf virus-PAV (BYDV-PAV) is one of the major viruses causing a widespread and serious viral disease affecting cereal crops. To gain a better understanding of plant defence mechanisms of BYDV resistance genes ( Bdv2 and Yd2 ) against BYDVPAV infection, the differences in agronomical, biochemical and histological changes between susceptible and resistant wheat and barley cultivars were investigated. We found that root growth and total dry matter of susceptible cultivars showed greater reduction than that of resistant ones after infection. BYDV infected leaves in susceptible wheat and barley cultivars showed a significant reduction in photosynthetic pigments, an increase in the concentration of reducing sugar. The protein levels were also low in infected leaves. There was a significant increase in total phenol contents in resistant cultivars, which might reflect a protective mechanism of plants against virus infection. In phloem tissue, sieve elements (SE) and companion cells (CC) were severely damaged in susceptible cultivars after infection. It is suggested that restriction of viral movement in the phloem tissue and increased production of phenolic compounds may play a role in the resistance and defensive mechanisms of both $B d v 2$ and $Y d 2$ against virus infection. 
1 Agronomical, biochemical and histological responses of resistant and susceptible wheat and 2 barley under BYDV stress

3

4 Shormin Choudhury ${ }^{1,}{ }^{4}$, Hongliang $\mathrm{Hu}^{1}$, Philip Larkin ${ }^{2}$, Holger Meinke ${ }^{1,3}$, Sergey Shabala ${ }^{3}$, 5 Ibrahim Ahmed ${ }^{1}$ and Meixue Zhou ${ }^{1}$

$6 \quad{ }^{1}$ TIA, University of Tasmania, University of Tasmania, Prospect, Australia

$7 \quad{ }^{2}$ CSIRO Agriculture and Food, Canberra, Australia

$8{ }^{3}$ Tasmanian Institute of Agriculture, University of Tasmania, Hobart, Australia

$9{ }^{4}$ Department of Horticulture, Faculty of Agriculture, Sher-e-Bangla Agricultural University, Sher10 e-Bangla Nagar, Dhaka, Bangladesh

12 Corresponding Author:

13 Meixue Zhou

14 Email address: meixue.zhou @utas.edu.au 


\section{ABSTRACT}

18 Barley yellow dwarf virus-PAV (BYDV-PAV) is one of the major viruses causing widespread and serious damage to cereal crops. To gain a better understanding of plant defence mechanisms of BYDV resistance genes ( $B d v 2$ and $R y d 2)$ against BYDV-PAV infection, we investigated the differences in agronomical, biochemical and histological changes between susceptible and resistant wheat and barley cultivars. We found that root growth and total dry matter of susceptible cultivars showed greater reduction than that of resistant cultivars after infection. BYDV infected leaves in susceptible wheat and barley cultivars showed a significant reduction in photosynthetic pigments and an increase in the concentration of reducing sugar. The protein levels were also low in infected leaves. There was a significant increase in total phenolic contents in resistant cultivars, which might reflect a protective mechanism of plants against virus infection. Phloem tissue, sieve elements (SE) and companion cells (CC) in susceptible cultivars showed severe damage after infection. We suggest that increased production of phenolic compounds may play a role in the resistance and defensive mechanisms of both $B d v 2$ and $R y d 2$ against virus infection. 


\section{INTRODUCTION}

Barley yellow dwarf virus-PAV (BYDV-PAV) is transmitted by aphids and has been recognized as one of the most serious viral pathogens of the Luteovirus genus that systemically infects cereal crops (Jiménez-Martínez et al., 2004). Infection with BYDV-PAV causes significant economic losses throughout the world (Huth, 2000; Ramsell et al., 2008). The use of resistant or tolerant varieties is an effective solution and economical method for controlling BYD disease (Ordon et al., 2004). Virus tolerance is the capability of a host genotype to survive or recover from the damaging effects of virus infection and yield, while resistance is the plant's ability to restrict or prevent the infection of virus (Cooper \& Jones, 1983). Wheat lines containing $B d v 2$ gene showed less yellowing and lower viral titer than susceptible wheat lines when infected by BYDV (Kausar et al., 2015). Similarly, barley cultivars containing Ryd2 also have lower virus titre after BYDV infection, which leads to less visual symptom and grain yield reduction (Beoni et al., 2016). Visual scoring of symptoms for BYDV-PAV resistance is not always useful as BYDV-PAV can multiply and spread in the plant without showing any visual symptoms (Horn, Habekuß \& Stich, 2013). Whole-plant metabolite profiles can be altered by virus infection (Shalitin \& Wolf, 2000; Xu et al., 2008). Through virus infection, many plant defence pathways can be activated or suppressed (Lewsey et al., 2010; Whitham, Yang \& Goodin, 2006).

BYDV is transmitted in a persistent, circulative and non-propagative manner (Conti et al., 1990, Masterman, Holmes \& Foster, 1994) and its transmission occur when an aphid feeds on infected phloem and phloem cells and then transfers the viruses in its saliva to healthy plants (Walling, 2008). Virus spread usually starts from cell-to-cell (short distance movement). In the later phase, the virus enters into the vascular tissue, where it is transported rapidly via phloem cells. This is referred to as long distance movement (Hipper et al., 2013, Waigmann et al., 2004). Plants infected by virus undergo strong metabolic and ultrastructural changes, even when no visible symptoms are apparent (Yan et al., 2008). Disease development in host plants is likely to induce substantial biochemical changes such as in protein, phenolics, carbohydrates, and these metabolic changes may favour or inhibit disease development (Ayres, Press \& Spencer-Phillips, 1996). In certain plant host-pathogen interactions, these alterations may play a major role in contributing to disease resistance. In crop breeding, the response of biochemical compounds in plants has been helpful to select fungal and insect resistant genotypes (Lattanzio et al., 2006). 
In chilli plants inoculated with pepper leaf curl virus (PepLCV), total phenolic content was increased in resistant cultivars and was decreased in susceptible cultivars (Rai et al., 2010). A positive correlation was observed in cocoa between cocoa swollen shoot virus disease (CSSVD) resistance and total phenolic contents at 3 months after inoculation (Ofori et al., 2015). Rapid synthesis of phenolics and their polymerization in the cell wall has been suggested as a plant defence response against infection (Sattler \& Funnell-Harris, 2013; Matern \& Kneusel, 1988), while low levels of phenolics may be linked to disease susceptibility (Yao, De Luca \& Brisson, 1995). However, there is no report on the relationship between total phenolic contents measured after BYDV infection and BYDV resistance in cereal crops.

Sugar metabolism is a dynamic process with both metabolic fluxes and sugar concentrations fluctuating strongly throughout plant development and in response to environmental signals for example circadian changes and biotic stresses (Bläsing et al., 2005; Borisjuk et al., 2003). In melon plants, cucumber mosaic virus infection causes a significant increase in the sugar content within the phloem (Shalitin \& Wolf, 2000). An increase in sugar concentration in tobacco leaves was caused by potato leafroll virus (PLRV) infection inhibiting phloem loading; the increased sugar led to the inhibition of photosynthesis (Herbers et al., 1997). Reduced translocation of sugar and other nutrient molecules to the root system limits root growth and function and thus affects plant growth and grain yield (Riedell et al., 2003). Biotic stress can also inhibit chlorophyll synthesis (Funayama-Noguchi \& Terashima, 2006; Šutić \& Sinclair, 1991), resulting in reduced photosynthesis. To date, many studies have been done with BYDV but little information has been reported regarding changes of biochemical compounds caused by BYDV infection in wheat and barley.

The aim of the study was to assess the response of different agronomical, biochemical and cell ultrastructural changes after systemic BYDV infection of susceptible and resistant wheat and barley plants, and to provide a better understanding of resistance mechanisms against BYDV-PAV infections.

\section{MATERIALS AND METHODS}

\section{Plant Material}

Two wheat (Triticum aestivum) cultivars (Manning and Revenue) and two barley (Hordeum vulgare) cultivars (Franklin and Flagship) were used in this study. Manning and Franklin are the 
94 95

96

97

98

99

100

101

102

103

104

105

106

107

108

109

110

111

112

113

114

115

116

117

118

119

120

121

122

123

124

cultivars with known BYDV resistance, containing $B d v 2$ (Ayala-Navarrete et al., 2007) and Ryd2 gene (Raman \& Read, 1999), respectively.

\section{Aphid colonies}

A colony of bird-cherry aphid, Rhopalosiphum padi, was collected from a Tasmanian barley field trial in 2014, and reared on barley (cv. TAM407227-a BYDV susceptible genotype) in a cage at $20{ }^{\circ} \mathrm{C} \pm 2{ }^{\circ} \mathrm{C}, 65 \pm 5 \% \mathrm{RH}$, with a photoperiod of L14:D10 using cool white fluorescent light under $450 \mu \mathrm{mol}-\mathrm{m}^{-2} \cdot \mathrm{s}^{-1}$ photosynthethically active radiation (PAR).

\section{Virus isolates}

One isolate of BYDV-PAV was obtained from the University of New England, New South Wales (NSW), Australia and maintained in barley cv. TAM407227 in small cages under the same conditions as the aphid colonies. The virus isolate was periodically (6-weekly) transferred to new plants using $R$. padi in clip cages.

\section{Plant growth and virus inoculation}

Ten seeds of each cultivar were sown in 21 plastic pots, which filled with pre-fertilized potting mixture. After germination, seedlings were thinned to five uniform and healthy plants in each pot. The plants were grown in a glasshouse, between September and November 2016. The average temperature was $23{ }^{\circ} \mathrm{C}$ in daytime and $15{ }^{\circ} \mathrm{C}$ at night with a relative humidity of 65 to $80 \%$. At two-leaf stage, each plant was inoculated with BYDV-PAV using ten viruliferous adult aphids (Rhopalosiphum padi) in a clip cage. An inoculation access period of $120 \mathrm{~h}$ was used to ensure virus infection of all plants. Aphids were then killed by spraying $1 \mathrm{ml} / \mathrm{L}$ solution of the insecticide Karate (Syngenta Ltd.).

\section{Leaf samples for biochemical analyses}

The most recent fully expanded leaves of both controls and inoculated plants were harvested at different growth stages, i.e. 3 and 6 weeks after inoculation (WAI), for various analysis. All biochemical parameters were measured using spectrophotometer (Genesys 10S UV-Vis).

\section{Photosynthetic pigments}


125 Photosynthetic pigments were measured using the method of (Moran \& Porath, 1980). $0.2 \mathrm{~g}$ leaf 126 tissue was ground into powder with liquid nitrogen, then homogenised with $1 \mathrm{ml} 100 \% \mathrm{~N}, \mathrm{~N}-$ 127 dimethylformamide (DMF). Homogenized samples were centrifuged at 10,000 x g for 10 min to 128 gather the supernatant. Then $1 \mathrm{ml}$ DMF was added again and samples were centrifuged. The 129 supernatant was removed and another $1 \mathrm{ml}$ DMF was added. The absorbance was recorded at 663 130 and $645 \mathrm{~nm}$ in a spectrophotometer. Calibration was done by using a blank of 100\% DMF. 131 Chlorophyll $\mathrm{a}, \mathrm{b}$ and total chlorophyll were calculated by following formulas:

132 Chlorophyll a $\left(\mathrm{mg} \mathrm{g}^{-1}\right.$ tissue $)=\frac{[12.7(0 D 663)-2.69(0 D 645)] / \times \mathrm{V}}{1000} \times W$

133 Chlorophyll b $\left(\mathrm{mg} \mathrm{g}^{-1}\right.$ tissue $)=\frac{[22.9(\text { OD645 })-4.68(\text { OD } 663)] / \times \mathrm{V}}{1000} \times W$

134 Total Chlorophyll $\left(\mathrm{mg} \mathrm{g}^{-1}\right.$ tissue $)=\frac{[8.02(\text { OD } 663)+20.20(\text { OD } 645)] / \times V}{1000} \times W$

135 Where OD: Optical density at respective nm, V: Final volume of chlorophyll extract,

136 W: Fresh weight of the tissue extracted

137

138

Measurement of total protein content

139 Total protein was estimated by using Bradford method (Bradford, 1976) and absorbance was 140 recorded at $595 \mathrm{~nm}$. Bovine serum albumin was used as standard. Protein contents in leaf samples 141 were recorded as $\mu \mathrm{g}$ of protein per gram of leaf tissue.

142

\section{Phenolic content}

144 Phenol content was measured using the method of Singleton, Orthofer \& Lamuela-Raventós 145 (1999). Fresh leaves (250 mg) were homogenized with 85\% methanol. The extract was centrifuged at $3000 \mathrm{~g}$ for $15 \mathrm{~min}$ at $10^{\circ} \mathrm{C}$ and the supernatant was separated. Folin \& Ciocalteu's reagent (2 $\mathrm{ml}$ ) was added to each $2 \mathrm{ml}$ of the supernatant. A sodium carbonate solution $(7.5 \%, 2 \mathrm{ml})$ was added to each test tube and after 30-45 min, the absorbance was read at wavelength $725 \mathrm{~nm}$ against a reagent blank. A standard curve using gallic acid was generated to determine the concentration of total phenols in the unknown sample.

\section{Reducing sugars content}

153 Reducing sugars were determined based on the method of phenol-sulphuric acid (DuBois et al., 154 1956). $0.2 \mathrm{~g}$ fresh leaf was homogenized with deionized water and the extract was filtered. $2 \mathrm{ml}$ of 
155 the solution were mixed with $0.4 \mathrm{ml}$ of $5 \%$ phenol. Subsequently, $2 \mathrm{ml}$ of $98 \%$ sulphuric acid were

156 added rapidly to the mixture. The test tubes were allowed to keep for $10 \mathrm{~min}$ at room temperature, 157 and placed in a water bath at $30^{\circ} \mathrm{C}$ for $20 \mathrm{~min}$ for colour development. Light absorption at $540 \mathrm{~nm}$

158 was then recorded with the spectrophotometer. Blank solution (distilled water) was prepared in the 159 same way as above (Ammar et al., 2009). Contents of reducing sugar was expressed as $\mathrm{mg} \mathrm{g}^{-1}$ 160 fresh weight (FW).

161

162

Biomass production

163 Four plants (above ground) were randomly sampled from each treatment and replication at 6 WAI. 164 After taking the fresh weight plant samples were kept in oven at $65^{\circ} \mathrm{C}$ for $72 \mathrm{~h}$ before recording 165 the weight of dry matter.

166

167

\section{Enzyme-linked immunosorbent assay (ELISA)}

Leaves from four plants of each treatment and replication were collected at 6 WAI for ELISA test. BYDV-PAV polyclonal antibodies (Sediag, France) were used in DAS-ELISA (Clark \& Adams, 1977) to detect the virus in leaf tissues. Samples were prepared by grinding $1 \mathrm{~g}$ leaf tissue in phosphate buffered saline, $\mathrm{pH} 7.4$, with $2 \%$ polyvinylpyrrolidone and $0.2 \%$ egg albumin in a ratio of 1:20. We used 2 healthy controls and 2 positive controls. All samples (control and BYDV-PAV inoculated leaves) and positive and negative controls were tested in duplicate. Microplates were read using a photometer (MR 5000 Dynatech) at wavelength $405 \mathrm{~nm}$. Our ELISA cut-off value is 2 times of the negative control (healthy control) in each test. Samples with absorbance values greater than twice the mean of negative controls were considered positive (Clark \& Adams, 1977).

\section{Histological examination}

Anatomical structure of infected and control wheat and barley leaves was examined with a light microscope using Leica DM500 (USA). Three biological replications were performed for each treatment. For microscopic examination, wheat leaves $\left(2 \times 2 \mathrm{~mm}^{2}\right)$ from both susceptible and resistant leaves were cassetted (Techno Plas, South Australia) using biopsy pads (Trajan Scientific and Medical, Victoria, Australia). Samples were then fixed in 10\% neutral buffered formaldehyde (Confix, ACFC, Australian Biostain, Traralgon, Victoria, Australia) for $24 \mathrm{~h}$ and processed 
186 Microsystems, Wetzlar, Germany). Samples were orientated on the EG1160 (Leica), embedded in 187 paraffin wax (Surgipath Paraplast, 39601006, Leica) and sectioned at 3 microns using Leica 188 RM2245 microtome and adhered to microscope slides (Menzel Glaser, Braunschweig, Germany) 189 for $20 \mathrm{~min}$ at $60{ }^{\circ} \mathrm{C}$. Sections were deparaffinised, rehydrated and stained using Jung autostainer 190 XL (Leica) for haematoxylin (Harris' Haematoxylin, AHHNA, Australian Biostain) and eosin, 191 dehydrated cleared and cover-slipped (Leica CV5030) using CV Mount (Leica, 046430011).

192

193

\section{Determination of root growth}

For root length measurement, five seedlings were grown in a 21 plastic pot filled with pre-fertilized 195 potting mixture. The plants were grown in a glasshouse with the average temperature of $15^{\circ} \mathrm{C}$ in daytime and $8 \mathrm{C}$ at night. Plant was inoculated with 10 viruliferous aphids for $120 \mathrm{~h}$. The experiment was terminated at $3 \mathrm{WAI}$ and root length was measured. The roots were carefully washed with tap water to separate substrates. The longest root length ( $\left.\mathrm{cm} \mathrm{plant}^{-1}\right)$ was measured as the distance from the base of the plant to the end of the longest root. Five biological replications were performed for each treatment.

201

202

\section{Data analysis}

203

The experiments used a randomized complete block design (RCBD) with three replications for

204 each cultivar and five plants in each replicate. Data were analysed using software SPSS 20.0. Two treatment means (the values of virus infected and control plants) were subjected to paired t-test. The value was considered to be statistically significant when $\mathrm{P}<0.05$. All results were presented with mean \pm SE from the replicates. Graphs were drawn using the Microsoft Excel program. We used ANOVA to test the effect of BYDV stress, cultivars and their interaction on biochemical parameters.

210

211

\section{RESULTS}

\section{Symptoms after inoculation}

213 Typical symptoms appeared on virus infected plants included leaf discoloration and dwarfism.

214 Leaf discoloration in both inoculated barley cultivars was visible within 3 WAI (Fig. 1). At 6 WAI 215 we did not observe leaf discoloration in either of the wheat cultivars, although the susceptible 216 cultivar showed evidence of dwarfism at that time (Fig. 2). 


\section{Validation of inoculation}

219

220

221

222

223

224

225

226

227

228

229

230

231

232

233

234

235

236

237

238

239

240

241

242

243

244

245

246

247

ELISA was used to confirm the virus infection of a plant, when ELISA values above the detection threshold (A 405>0.32) were assumed to illustrate the presence of virus particles. The virus extinction value was the highest in BYDV inoculated susceptible barley plant (Flagship) followed by susceptible wheat (Revenue) and the lowest value was detected in resistant wheat variety (Manning) (Fig. 3), suggesting that both the Ryd2 gene of barley and the $B d v 2$ gene of wheat reduced the viral load.

\section{The effect of virus infection on root growth}

At 3 WAI, all inoculated wheat and barley cultivars showed reduced root length compared to the control (Figs. 4A-4D). Susceptible barley and wheat cultivars showed significantly greater reduction of root length by $41 \%$ and $36 \%$ for Revenue and Flagship, respectively. In contrast, resistant barley (Franklin) and wheat (Manning) only exhibited 7\% ( $>0.05)$ and 13\% $(\mathrm{p}<0.05)$ reduction, respectively (Fig. 4E).

\section{Photosynthetic pigments}

At $3 \mathrm{WAI}$, the contents of photosynthetic pigments were significantly reduced in virus infected plants of both resistant and susceptible cultivars compared to the control. No significant interactions were found in cultivar $\times$ treatment for all photosynthetic pigments at 3 WAI (Table S1) even though greater reductions were found in susceptible ones. The average reductions in chlorophyll a, chlorophyll $\mathrm{b}$ and total chlorophyll were $33 \%, 50 \%$, and $38 \%$, respectively for Revenue, and 24\%, 38\% and 28\%, respectively, for Flagship (Figs. 5A-5C).

At 6 WAI, the difference in photosynthetic pigments between inoculated and control plants of the two resistant wheat and barley cultivars were insignificant. In contrast, further reductions in photosynthetic pigments were found in the two susceptible cultivars (Fig. 5D-5F and Table S1).

\section{Total protein}

In wheat, virus infection caused a significant reduction in foliar protein contents only of susceptible wheat cultivar (Revenue) but not of the other cultivars at 3WAI $(\mathrm{P}<0.05)$ (Fig. 6A). At 6 WAI, both susceptible and resistant barley and wheat cultivars showed significant reduction in protein 
248 content in virus infected plants. Significant cultivar $\times$ treatment interaction was found on protein

249 content at 6 WAI (Table S1). The reduction was observed more in susceptible cultivars Flagship 250 (28\%) and Revenue (27\%) whereas the reductions in Manning and Franklin were only 9\% and $25111 \%$, respectively (Fig. 6B).

252

253 Total phenol

254 At early stage (3 WAI) of virus infection, significant differences in total phenol contents were 255 found among cultivars (Table S1). However, total phenol contents were not significantly different 256 between virus infected and control plants of all cultivars (Fig. 7A and Table S1).

257 However, at $6 \mathrm{WAI}$, significant increases in total phenol contents were found in virus infected 258 plants of all cultivars. The increase in total phenol contents was more pronounced in the resistant 259 cultivars (19-25\%) than susceptible ones (5-6\%) (Fig. 7B), indicating a significant cultivar $\times$ 260 treatment interaction (Table S1)

\section{Reducing sugar}

Figures $8 \mathrm{~A}-8 \mathrm{~B}$ show that virus infection caused an increase in leaf sugar content of both

264

265

266

267

268

269

270

271

272

273

274

275

276

277 278 susceptible and resistant cultivars. Wheat cultivars had lower sugar contents than barley cultivars earlier at 3 WAI but they were similar to the barley cultivars at later stage (6 WAI). Significant cultivar $\times$ treatment interactions were found on sugar content at 6 WAI (Table S1). Susceptible cultivars showed a greater increase in reducing sugar contents in virus infected plants than resistant ones, being 9\%, 26\%, 13\% and 35\% at 6 WAI for Manning, Revenue, Franklin and Flagship, respectively (Fig. 8B).

\section{Biomass production}

Significant differences in biomass were found in BYDV inoculated and non-inoculated control plants for all cultivars. The reduction of fresh weight varied with cultivar, with the lowest reduction occurring in the resistant wheat cultivar Manning (4\%) and the highest in the susceptible wheat cultivar Revenue (41\%) (Fig. 9A). Similar trend was found for the dry matter production. Greater reductions in dry matter were observed in Flagship (25\%) and Revenue (22\%) whereas the reductions in the resistant cultivars Manning and Franklin were only $6 \%$ and $9 \%$, respectively (Fig. 9B). 


\section{Alteration of leaf ultrastructure}

281

282

283

284

285

286

287

288

289

290

291

292

293

294

295

296

297

298

299

300

301

302

303

304

305

306

307

308

Ultrastructural examinations of the phloem tissue of leaves from all cultivars were conducted at 6 WAI. The sections of leaf venial regions of non-inoculated plants showed a typical structure of vascular bundles in both wheat and barley. The sieve elements (SE) and the companion cell (CC) are well organised in the phloem tissue with each SE being adjoined by CC (Fig. 10A, C \& 11A, C).

In virus infected barley plants, the phloem tissue of leaf veins consisted of smaller, denser and disorganised SE, with no adjacent CC. In addition, in the susceptible barley cultivar Flagship the SE became necrotic, covered with dark stain and the CCs were degenerated (Fig. 10B). Different results were observed in the resistant cultivar Franklin, which had normal SE with adjacent CC. Although these were looking almost the same as non-inoculated leaves, the $\mathrm{CC}$ seems to have reduced size compared with control. Necrotic regions were also observed in some vascular bundles in Flagship (Fig. 10B). In the susceptible wheat, BYDV-PAV inoculated leaf showed infected phloem parenchyma (IPP) and infected sieve elements (ISE)(Fig. 11B). The resistant wheat plant had similar cellular structures of SE and CC in virus infected and control leaves, thus vascular bundle was not affected in virus infected resistant wheat cv. Manning (Fig. 11D).

\section{DISCUSSION}

BYDV-PAV is one of the most destructive diseases of wheat and barley, which often causing significant yield losses when susceptible cultivars are grown (Jarošová et al., 2013). To reduce BYD disease damage, the use of resistant cultivars is the most cost-effective and environmentally sound approach. For a better understanding of the mechanism of plant resistance to BYD disease, we investigated the changes of biochemical and ultrastructural characteristics in susceptible and resistant wheat and barley cultivars.

Reduction in chlorophyll content has been reported in many host plants infected with different viruses. The virus infection reduces chlorophyll contents of leaves producing chlorosis (Pineda et al., 2008; Vimla \& Shukla, 2009). In our experiment, at 6 WAI susceptible cultivars showed a significant decrease in the rate of photosynthetic pigments. The reduced chlorophyll contents in 
309

310

311

312

313

314

315

316

317

318

319

320

321

322

323

324

325

326

327

328

329

330

331

332

333

334

335

336

337

338

susceptible cultivars are mainly due to a loss of leaf photosynthetic area and chloroplast disorders as observed in bean mosaic virus infected vicia faba leaves (Radwan et al., 2008) while resistant gene can prevent the loss of chlorophyll in virus-infected leaves as shown in resistant tomato genotype after TMV infection (Fraser \& Loughlin, 1980). Yellow vein mosaic virus (YVMV) infection can cause enhanced activity of the chlorophyllase that attack chlorophyll and inhibit chloroplast development and chlorophyll synthesis in okra leaves (Ahmed, Thakur \& Bajaj, 1986). The reduced photosynthesis capacity caused by reduced content of photosynthetic pigments contributes to the decrease in biomass production, which is shown in our studies as well as previous reports on BYDV infected cereals (Bukvayová et al., 2006). Resistant cultivars infected with BYDV showed little effect on plant biomass, indicated resistant genotypes were able to maintain plant growth upon virus infection.

At early stages of plant development, screening of root traits can be used as a proxy for mature stages (Comas et al., 2013). Greater root length contributed to enhanced grain yield of wheat by permitting more water extraction at grain filling stage (Manschadi et al., 2006). Barley yellow dwarf virus (BYDV) affected the root elongation in wheat and barley cultivars differing in their response to BYDV, the reduction of total root length was less severe in the resistant cultivars than susceptible cultivars, which is shown in our results as well as previous reports on BYDV infected oat cultivars (Kolb et al., 1991). Root length is associated with plant height (Steele et al., 2006). Reduction in root length severely restricted water and nutrient absorption process, which may lead to the decreased of shoot growth (Riedell et al., 2003).

Long-distance movement of virus particles is known to occur via the phloem, following the stream of sugar transport (Gilbertson \& Lucas, 1996; Maule \& Palukaitis, 1991). In sugarcane leaves infected by sugarcane mosaic virus (SCMV), sugar concentration is increased as a result of inhibited phloem transport (Addy et al., 2017). Fiebig et al. (2004) measured sugar content in phloem sap of BYDV infected and non-infected wheat plants and observed that there was no significant differences between control and infected plants. It is possibly BYDV blocked sugar movement into the phloem and consequently the rate of sugar movement was reduced, thus its concentration within the cells was higher. In this study, leaves infected with BYDV had significantly increased content of reducing sugar in susceptible cultivars. Likewise, Jensen (1969, 1968) showed that BYDV infected plants had greater accumulation of carbohydrate in leaves, and 
339 a corresponding reduced chlorophyll content and rate of photosynthesis. The results of our study 340 were similar to those found in a study of sunflower chlorotic mottle virus (SuCMoV) on sunflower 341 in which infected leaves showed higher sugar accumulation and lower shoot biomass (Arias et al., 342 2003). Misra \& Jha (1971) observed an increase in reducing sugar in chilli leaves affected by 343 mosaic virus, as did Gonçalves et al. (2005) in sugarcane leaves affected by sugarcane yellow leaf 344 virus (ScYLV), possibly as a result of disruption of normal phloem transport or phloem loading. 345 Shalitin \& Wolf (2000) found that increased foliar sugar levels in melon plants following infection 346 by cucumber mosaic virus were accompanied by increased respiration, which may lead to biomass 347 reduction.

Protein components has been reported to be involved in plant pathogenic interactions (Carvalho et al., 2006; Tornero et al., 2002) with BYDV susceptible wheat cultivars showing significant reductions in protein content (Xu et al., 2016). In the current experiment, significant reduction in protein content at $6 \mathrm{WAI}$ was also found in resistant cultivars, which is different from the report of Sahhafi et al. (2012) that resistant wheat maintained higher protein content under wheat streak mosaic virus infection.

Phenolic compounds are often associated with plant responses to different stresses 355 (Freeman \& Beattie, 2008), with higher accumulation of phenols in resistant genotypes compared 356 to susceptible ones in other virus/plant interactions (Siddique et al., 2014; Singh et al., 2010). Deposition of phenolics in plant cell walls might be a possible mechanism of virus resistance by playing key roles in increasing mechanical strength of host cell (Boudet, Lapierre \& Grima-Pettenati, 1995) and inducing cell wall lignification as lignin precursors (Lyon et al., 1992). In the present study, at $3 \mathrm{WAI}$ phenolic content was increased only in virus infected resistant genotypes. In addition, the total phenolic content was significantly increased in all infected resistant genotypes at 6 WAI but not in susceptible ones, suggesting that both increased rate and quantity of phenolics might be components of the defence mechanism of $B d v 2$ and $R y d 2$ resistance genes.

In a vascular bundle, $\mathrm{SE}$ and $\mathrm{CC}$ participate in metabolic activities, and are responsible for long distance transport of minerals and assimilates. Viruses have been shown to affect both the structural and functional activities of the SE and CC (Lalonde, Camera \& Frommer, 2001). BYDV 368 is a systemic virus and its replication is almost entirely restricted within the plant phloem tissue 
369 (Irwin \& Thresh,1990). BYDV particles are found exclusively in vasculature samples (Gill \& 370 Chong, 1975). Any restriction to phloem tissues will impact virus dispersal. However, there is also 371 evidence of cell-to-cell movement of luteoviruses between nucleate cells of the phloem tissues 372 (Mutterer et al., 1999).

373

374 Conclusion

375 Although the damage to vasculature in BYDV infected plants remains to be quantified, we might 376 speculate that accumulating viral load in the phloem leads to more widespread damage to the 377 vasculature, and inhibition of sugar transport, which in turn inhibits root and biomass growth. The 378 increased sugar content of leaves may also inhibit photosynthesis resulting in a further cycle of 379 growth constraint. We hypothesise that the capacity to respond to virus with inhibitory phenolic 380 compounds may be the basis of $B d v 2$ and Ryd2 resistance, limiting viral load and the cascade of 381 pathological events described above.

382

383

ACKNOWLEDGEMENTS

384

385 386

387

388

389

390

391

392

393

394

395

396

397

The authors would like to thanks Dr Fiona Kerslake and Dane Hayes for their help during biochemical analysis and ultrastructure examination respectively

\section{References}

Addy HS, Wahyudi AHS, Sholeh A, Anugrah C, Iriyanto FES, Darmanto W, Sugiharto B. 2017. Detection and Response of Sugarcane against the Infection of Sugarcane Mosaic Virus (SCMV) in Indonesia. Agronomy 7:1-11 DOI 10.3390/agronomy7030050

Ahmed N, Thakur M, Bajaj K. 1986. Nature of resistance and effect of yellow vein mosaic virus on moisture, chlorophyll, chlorophyllase and carbohydrate contents of okra. Vegetable Science 13:339-353.

Ainsworth EA, Bush DR. 2011. Carbohydrate export from the leaf: a highly regulated process and target to enhance photosynthesis and productivity. Plant Physiology 155:64-69 DOI https://doi.org/10.1104/pp.110.167684. 
398 399

400

401

402

403

404

405

406

407

408

409

410

411

412

413

414

415

416

417

418

419

420

421

422

423

424

425

426

427

428

Ammar E-D, Tsai C-W, Whitfield AE, Redinbaugh MG, Hogenhout SA. 2009. Cellular and molecular aspects of rhabdovirus interactions with insect and plant hosts. Annual Review of Entomology 54:447-468 DOI 10.1146/annurev.ento.54.110807.090454.

Arias MC, Lenardon S, Taleisnik E. 2003. Carbon metabolism alterations in sunflower plants infected with the Sunflower chlorotic mottle virus. Journal of Phytopathology 151:267273 DOI 10.1046/j.1439-0434.2003.00718.x.

Ayala-Navarrete L, Bariana H, Singh R, Gibson J, Mechanicos A, Larkin P. 2007. Trigenomic chromosomes by recombination of Thinopyrum intermedium and Th. ponticum translocations in wheat. Theoretical and Applied Genetics 116:63-75 DOI 10.1007/s00122-007-0647-5.

Ayres PG, Press MC, Spencer-Phillips PT. 1996. Effects of pathogens and parasitic plants on source-sink relationships. Photoassimilate Distribution in Plants and Crops 8:479-499.

Beoni E, Chrpova J, Jarosova J, Kundu JK. 2016. Survey of Barley yellow dwarf virus incidence in winter cereal crops, and assessment of wheat and barley resistance to the virus. Crop and Pasture Science 67:1054-1063 DOI 10.1071/CP16167

Bläsing OE, Gibon Y, Günther M, Höhne M, Morcuende R, Osuna D, Thimm O, Usadel B, Scheible W-R, Stitt M. 2005. Sugars and circadian regulation make major contributions to the global regulation of diurnal gene expression in Arabidopsis. The Plant Cell 17:32573281 DOI https://doi.org/10.1105/tpc.105.035261.

Borisjuk L, Rolletschek H, Wobus U, Weber H. 2003. Differentiation of legume cotyledons as related to metabolic gradients and assimilate transport into seeds. Journal of Experimental Botany 54:503-512 DOI https://doi.org/10.1093/jxb/erg051.

Boudet A, Lapierre C, Grima-Pettenati J. 1995. Biochemistry and molecular biology of lignification. New Phytologist 129:203-236 DOI 10.1111/j.1469 8137.1995.tb04292.x.

Bradford MM. 1976. A rapid and sensitive method for the quantitation of microgram quantities of protein utilizing the principle of protein-dye binding. Analytical Biochemistry 72:248-254.

Bukvayová N, Henselová M, Vajcíková V, Kormanová T. 2006. Occurrence of dwarf virus of winter wheat and barley in several regions of Slovakia during the growing seasons 20012004. Plant, Soil and Environment 52:392.

Carvalho Dd, Ferreira RA, Oliveira LMd, Oliveira AFd, Gemaque RCR. 2006. Proteins and isozymes electroforesis in seeds of Copaifera Langsdorffii Desf.(leguminosae 
429

430

431

432

433

434

435

436

437

438

439

440

441

442

443

444

445

446

447

448

449

450

451

452

453

454

455

456

457

458

459

caesalpinioideae) artificially aged. Revista Árvore 30:19-24 DOI http://dx.doi.org/10.1590/S0100-67622006000100003.

Clark MF, Adams A. 1977. Characteristics of the microplate method of enzyme-linked immunosorbent assay for the detection of plant viruses. Journal of General Virology 34:475-483.

Comas L, Becker S, Cruz VMV, Byrne PF, Dierig DA. 2013. Root traits contributing to plant productivity under drought. Frontiers in Plant Science 4:442 DOI https://doi.org/10.3389/fpls.2013.00442.

Conti M, Darcy CJ, Jedlinski H, Burnett PA. 1990. The 'yellow plague' of cereals, barley yellow dwarf virus. In: World perspectives on Barley Yellow Dwarf. Burnett PA (ed), pp 1-6. Mexico City: CIMMYT

Cooper J, Jones A. 1983. Responses of plants to viruses: proposals for the use of terms. Phytopathology 73:127-128.

DuBois M, Gilles KA, Hamilton JK, Rebers Pt, Smith F. 1956. Colorimetric method for determination of sugars and related substances. Analytical Chemistry 28:350-356 DOI 10.1021/ac60111a017.

Fiebig M, Poehling HM, Borgemeister C. 2004. Barley yellow dwarf virus, wheat, and Sitobion avenae: a case of trilateral interactions. Entomologia Experimentalis et Applicata 110:1121.

Fraser R, Loughlin S. 1980. Resistance to tobacco mosaic virus in tomato: effects of the Tm-1 gene on virus multiplication. Journal of General Virology 48:87-96 DOI 10.1099/00221317-48-1-87.

Freeman BC, Beattie GA. 2008. An overview of plant defenses against pathogens and herbivores. The Plant Health Instructor DOI 10.1094/PHI-I-2008-0226-01.

Funayama-Noguchi S, Terashima I. 2006. Effects of Eupatorium yellow vein virus infection on photosynthetic rate, chlorophyll content and chloroplast structure in leaves of Eupatorium makinoi during leaf development. Functional Plant Biology 33:165-175.

Gilbertson RL, Lucas WJ. 1996. How do viruses traffic on the 'vascular highway'? Trends in Plant Science 1:250-251 DOI 10.1016/1360-1385(96)10029-7.

Gill C, Chong J. 1975. Development of the infection in oat leaves inoculated with barley yellow dwarf virus. Virology 66:440-453 DOI 10.1016/0042-6822(75)90216-0. 
460 Gonçalves MC, Vega J, Oliveira JG, Gomes M. 2005. Sugarcane yellow leaf virus infection leads

461

462

463

464

465

466

467

468

469

470

471

472

473

474

475

476

477

478

479

480

481

482

483

484

485

486

487

488 to alterations in photosynthetic efficiency and carbohydrate accumulation in sugarcane leaves. Fitopatologia Brasileira 30:10-16 DOI: 10.1590/S0100-41582005000100002.

Herbers K, Tacke E, Hazirezaei M, Krause KP, Melzer M, Rohde W, Sonnewald U. 1997. Expression of a luteoviral movement protein in transgenic plants leads to carbohydrate accumulation and reduced photosynthetic capacity in source leaves. The Plant Journal 12:1045-1056 DOI: 10.1046/j.1365-313X.1997.12051045.x.

Hipper C, Brault V, Ziegler-Graff, V. Revers, F. 2013. Viral and cellular factors involved in phloem transport of plant viruses. Frontiers in Plant Science 4:154 DOI 10.3389/fpls.2013.00154. eCollection 2013

Horn F, Habekuß A, Stich B. 2013. Natural variation for BYDV resistance in maize. Maydica 58:173-181.

Huth W. 2000. Viruses of Gramineae in Germany-a short overview/Viren der Gramineen in Deutschland-ein kurzer Überblick. Zeitschrift für Pflanzenkrankheiten und Pflanzenschutz/Journal of Plant Diseases and Protection 1:406-414.

Irwin M, Thresh J. 1990. Epidemiology of barley yellow dwarf: a study in ecological complexity. Annual Review of Phytopathology 28:393-424 DOI 10.1146/annurev.py.28.090190.002141.

Jarošová J, Chrpová J, Šíp V, Kundu J. 2013. A comparative study of the Barley yellow dwarf virus species PAV and PAS: distribution, accumulation and host resistance. Plant Pathology 62:436-443 DOI 10.1111/j.1365-3059.2012.02644.x.

Jensen SG. 1969. Composition and metabolism of barley leaves infected with barley yellow dwarf virus. Phytopathology.59:1694:1698

Jensen SG. 1968. Photosynthesis, respiration and other physiological relationships in barley infected with barley yellow dwarf virus. Phytopathology 58:204-208.

Jiménez-Martínez E, Bosque-Pérez N, Berger P, Zemetra R. 2004. Life history of the bird cherryoat aphid, Rhopalosiphum padi (Homoptera: Aphididae), on transgenic and untransformed wheat challenged with Barley yellow dwarf virus. Journal of Economic Entomology 97:203-212 DOI 10.1603/0022-0493-97.2.203. 
489 Kausar S, Hameed S, Saleem K, Ul Haque I, Zamurrad M, Ashfaq M. 2015. Molecular

490

491

492

493

494

495

496

497

498

499

500

501

502

503

504

505

506

507

508

509

510

511

512

513

514

515

516

517

518

confirmation of Bdv2 gene in wheat germplasm and its field based assessment for resistance against barely yellow dwarf viruses. Advancements in Life Sciences 3:16-22

Kolb F, Cooper N, Hewings A, Bauske E, Teyker R. 1991. Effects of barley yellow dwarf virus on root growth in spring oat. Plant Disease 75:143-145

Lalonde S, Franceschi VR, Frommer WB. 2001. Companion Cells. Encyclopedia of Life Sciences https://pdfs.semanticscholar.org/3f98/b6a4c8fda10df6cd702e8fbc01a03ef64a8b.pdf

Lattanzio V, Lattanzio VM, Cardinali A. 2006. Role of phenolics in the resistance mechanisms of plants against fungal pathogens and insects. Phytochemistry: Advances in Research 661:23-67.

Lewsey MG, Murphy AM, MacLean D, Dalchau N, Westwood JH, Macaulay K, Bennett MH, Moulin M, Hanke DE, Powell G. 2010. Disruption of two defensive signaling pathways by a viral RNA silencing suppressor. Molecular Plant-Microbe Interactions 23:835-845 DOI 10.1094/ MPMI -23-7-0835.

Lyon G, Heilbronn J, Forrest R, Johnston D. 1992. The biochemical basis of resistance of potato to soft rot bacteria. Netherlands Journal of Plant Pathology 98:127-133.

Manschadi AM, Christopher J, Hammer GL 2006. The role of root architectural traits in adaptation of wheat to water-limited environments. Functional Plant Biology 33:823-837 https://doi.org/10.1071/FP06055.

Masterman AJ, Holmes SJ, Foster GN. 1994. Transmission of barley yellow dwarf virus by cereal aphids collected from different habitats on cereal farms. Plant Pathology 43: 612-620.

Matern U, Kneusel RE. 1988. Phenolic compounds in plant disease resistance. Phytoparasitica $16: 153-170$.

Maule AJ, Palukaitis P. 1991. Virus movement in infected plants. Critical Reviews in Plant Sciences 9:457-473 https://doi.org/10.1080/07352689109382301.

Misra A, Jha A. 1971. Changes in protein and carbohydrate content of mosaic virus infected chilli plants. Indian Journal of Plant Physiology: Official Publication of the Indian Society for Plant Physiology 14.

Moran R, Porath D. 1980. Chlorophyll determination in intact tissues using N, Ndimethylformamide. Plant Physiology 65:478-479. 
519 Mutterer J, Stussi-Garaud C, Michler P, Richards K, Jonard G, and Ziegler-Graff V. 1999. Role 520 of the beet western yellows virus readthrough protein in virus movement in Nicotiana 521 clevelandii. Journal of General Virology 80:2771-2778.

522 Ofori A, Padi FK, Ameyaw GA, Dadzie AM, Lowor S. 2015. Genetic variation among cocoa 523 (Theobroma cacao L.) families for resistance to cocoa swollen shoot virus disease in 524 relation to total phenolic content. Plant Breeding 134:477-484 DOI 10.1111/pbr.12282.

525 Ordon F, Friedt W, Scheurer K, Pellio B, Werner K, Neuhaus G, Huth W, Habekuss A, Graner A. 526 2004. Molecular markers in breeding for virus resistance in barley. Journal of Applied 527 Genetics 45:145-160.

528 Pineda M, Soukupová J, Matouš K, Nedbal L, Barón M. 2008. Conventional and combinatorial 529 530 chlorophyll fluorescence imaging of tobamovirus-infected plants. Photosynthetica 46:441451

531

532

533

534

535

536

537

538

539

540

541

542

543

544

545

546

547

548

549

Radwan DEM, Lu G, Fayez KA, Mahmoud SY. 2008. Protective action of salicylic acid against bean yellow mosaic virus infection in Vicia faba leaves. Journal of Plant Physiology 165:845-857 DOI https://doi.org/10.1016/j.jplph.2007.07.012.

Rai VP, Jaiswal N, Kumar S, Singh S, Kumar R, Rai A. 2010. Response of total phenols and peroxidase activity in Chilli exposed to pepper leaf curl virus disease. Vegetable Science 37:78-80.

Raman H, Read B. 1999. Efficient marker assisted selection for resistance to barley yellow dwarf virus using leaf tissue and sap as templates in barley. Barley Genetics Newsletter.

Ramsell J, Lemmetty A, Jonasson J, Andersson A, Sigvald R, Kvarnheden A. 2008. Sequence analyses of Wheat dwarf virus isolates from different hosts reveal low genetic diversity within the wheat strain. Plant Pathology 57:834-841 DOI 10.1111/j.13653059.2008.01862.x.

Riedell WE, Kieckhefer RW, Langham MA, Hesler LS. 2003. Root and Shoot Responses to Bird Cherry-Oat Aphids and in Spring Wheat. Crop Science 43:1380-1386 DOI 10.2135/cropsci2003.1380.

Sahhafi SR, Bagheri F, Assad MT, Masumi M, Talebi M. 2012. Evaluation of Some Biochemical Responses in Resistance of Fifteen Bread Wheat (Triticum aestivum L.) Genotypes to Wheat streak mosaic virus. Journal of Agricultural Science 4:75 DOI http://dx.doi.org/10.5539/jas.v4n5p75. 
550 Shalitin D, Wolf S. 2000. Cucumber mosaic virus infection affects sugar transport in melon plants.

551

552

553

554

555

556

557

558

559

560

561

562

563

564

565

566

567

568

569

570

571

572

573

574

575

576

577

578

579

Plant Physiology 123:597-604 DOI https://doi.org/10.1104/pp.123.2.597.

Sattler S, Funnell-Harris D. 2013. Modifying lignin to improve bioenergy feedstocks: strengthening the barrier against pathogens? Frontiers in Plant Science 4:70 DOI https://doi.org/10.3389/fpls.2013.00070.

Siddique Z, Akhtar KP, Hameed A, Sarwar N, Imran-Ul-Haq, Khan SA. 2014. Biochemical alterations in leaves of resistant and susceptible cotton genotypes infected systemically by Cotton leaf curl Burewala virus. Journal of Plant Interactions 9:702-711 DOI https://doi.org/10.1080/17429145.2014.905800.

Singh A, Singh K, Rajwar G, and Singh U. 2010. Phenolic acid content-a criterion for selection of resistant apple cultivars against Podosphaera leucotricha (Ell. and Ev.) Salmon. Archives of Phytopathology and Plant Protection 43:1138-1143 DOI https://doi.org/10.1080/03235400802343817

Singleton VL, Orthofer R, and Lamuela-Raventós RM. 1999. Analysis of total phenols and other oxidation substrates and antioxidants by means of folin-ciocalteu reagent. Methods in Enzymology 299:152-178 https://doi.org/10.1016/S0076-6879(99)99017-1.

Steele K, Price AH, Shashidhar H, Witcombe J. 2006. Marker-assisted selection to introgress rice QTLs controlling root traits into an Indian upland rice variety. Theoretical and Applied Genetics 112:208-221 DOI 10.1007/s00122-005-0110-4.

Šutić DD, and Sinclair JB. 1991. Anatomy and Physiology of Diseased Plants: CRC press.

Tornero P, Chao RA, Luthin WN, Goff SA, Dangl JL. 2002. Large-scale structure-function analysis of the Arabidopsis RPM1 disease resistance protein. The Plant Cell 14:435-450 DOI https://doi.org/10.1105/tpc.010393

Vimla S, Shukla K. 2009. Effect of PRSV infection on pigment content and assimilation of carbohydrate in Carica papaya L. Annals of Plant Protection Sciences 17:152-156

Waigmann E, Ueki S, Trutnyeva K, and Citovsky V. 2004. The ins and outs of nondestructive cellto-cell and systemic movement of plant viruses. Critical Reviews in Plant Sciences 23:195250 DOI https://doi.org/10.1080/07352680490452807.

Walling LL. 2008. Avoiding effective defenses: strategies employed by phloem-feeding insects. Plant Physiology 146:859-866 DOI: https://doi.org/10.1104/pp.107.113142. 
580 Whitham SA, Yang C, Goodin MM. 2006. Global impact: elucidating plant responses to viral 581 infection. Molecular Plant-Microbe Interactions 19:1207-1215 DOI 582 https://doi.org/10.1094/MPMI-19-1207.

583 Xu L, Hou Q, Zhao Y, Ni Z, Liang H, Liang R. 2016. Biochemical responses of resistant and 584 susceptible wheat cultivars to English grain aphid (Sitobio avenae F.) at grain-filling stage. 585 Academia Journal of Biotechnology 4:276-284 DOI 10.15413/ajb.2016.0278.

586 Xu P, Chen F, Mannas JP, Feldman T, Sumner LW, Roossinck MJ. 2008. Virus infection improves 587 drought tolerance. New Phytologist 180:911-921 DOI: 10.1111/j.1469-

Yan S-L, Lehrer A, Hajirezaei M, Springer A, Komor E. 2008. Modulation of carbohydrate 590

Yao K, De Luca V, Brisson N. 1995. Creation of a metabolic sink for tryptophan alters the 594 phenylpropanoid pathway and the susceptibility of potato to Phytophthora infestans. The 595 Plant Cell 7:1787-1799 DOI: https://doi.org/10.1105/tpc.7.11.178

596

597 
598

599

600

601

602

603

604

605

606

607

608

609

610

611

612

613

614

615

616

617

618

619

620

621

622

623

\section{Legends of Figures}

Figure 1 BYDV-PAV inoculated (B) and control (A) plants of susceptible barley cultivar Flagship at $3 \mathrm{WAI}$.

Figure 2 BYDV-PAV inoculated (B) and control (A) plants of susceptible wheat cultivar Revenue at $6 \mathrm{WAI}$.

Figure 3 Mean virus extinction (A $405 \mathrm{~nm}$ ) assessed in leaf extracts of BYDV-PAV inoculated and control plants of wheat (W) and barley (B) cultivars at 6 WAI. Mean \pm SE $(n=9)$ *: significant at $\mathrm{P}<0.05$ level.

Figure 4: Root appearance (A,B,C,D) and average root length (E) of BYDV-PAV inoculated and control plants of wheat (W) and barley (B) cultivars at 3 WAI. Mean $\pm \operatorname{SE}(n=5)$. *: significant at $\mathrm{P}<0.05$ level.

Figure 5 Average content (mg/g) of chlorophyll a, chlorophyll b, and total chlorophyll of BYDVPAV inoculated and control plants of wheat (W) and barley (B) cultivars at 3 WAI (A,B,C) and 6 WAI (D,E,F). Mean $\pm \mathrm{SE}(\mathrm{n}=6)$. * : significant at $\mathrm{P}<0.05$ level.

Figure 6 Average content (mg/g leaf fresh weight) of total protein of BYDV-PAV inoculated and control plants of wheat (W) and barley (B) cultivars at 3 WAI (A) and 6 WAI (B). Mean \pm $\mathrm{SE}(\mathrm{n}=6)$. *: significant at $\mathrm{P}<0.05$ level.

Figure 7 Average content (mg/g leaf fresh weight) of total phenol of BYDV-PAV inoculated and control plants of wheat (W) and barley (B) cultivars at 3 WAI (A) and 6 WAI (B). Mean \pm $\mathrm{SE}(\mathrm{n}=6)$. *: significant at $\mathrm{P}<0.05$ level.

Figure 8 Average content of (mg/g leaf fresh weight) reducing sugar of BYDV-PAV inoculated and control plants of wheat (W) and barley (B) cultivars at 3 WAI (A) and 6 WAI (B). Mean $\pm \operatorname{SE}(\mathrm{n}=6) . *$ : significant at $\mathrm{P}<0.05$ level.

Figure 9 Average shoot fresh weight (g) (A) and relative dry matter (B) of BYDV-PAV inoculated and control plants of wheat (W) and barley (B) cultivars at 6 WAI. Mean \pm SE (n=9). *: significant at $\mathrm{P}<0.05$ level. 
624 Figure 10 Transverse sections of foliar vascular bundles of susceptible (Flagship) and resistant 625 (Franklin) barley cultivars; A, C from control plants and B, D from BYDV-PAV inoculated 626 plants. Details are $\mathrm{SE}=$ sieve elements, $\mathrm{CC}=$ companion cell, $\mathrm{NSE}=$ necrotic sieve elements, $627 \quad$ LISE $=$ little infected sieve elements. Mean \pm SE $(n=3)$.

628 Figure 11 Transverse sections of foliar vascular bundles of susceptible (Revenue) and resistant 629 (Manning) wheat cultivars; A, C from control plants and B, D from BYDV-PAV inoculated 630 plants. Details are $\mathrm{SE}=$ sieve elements, $\mathrm{CC}=$ companion cell, $\mathrm{ISE}=$ infected sieve elements, 631 IPP $=$ infected phloem parenchyma. Mean $\pm \mathrm{SE}(\mathrm{n}=3)$. 
634 Table S1 Analysis of variance (F-value) for different biochemical parameters of wheat and barley 635 cultivars as affected by main factors (cultivars and treatment) and their interaction

636

\begin{tabular}{|c|c|c|c|c|c|c|c|c|c|}
\hline \multirow[b]{2}{*}{ Parameter } & \multirow[b]{2}{*}{$\begin{array}{l}\text { Source of } \\
\text { variation }\end{array}$} & \multicolumn{4}{|c|}{ At 3 weeks after inoculation } & \multicolumn{4}{|c|}{ At 6 weeks after inoculation } \\
\hline & & S.S. & D.F. & M.S. & $\mathbf{F}$ & S.S. & D.F. & M.S. & $\mathbf{F}$ \\
\hline \multirow[t]{4}{*}{ Chl a } & Cultivar & 2.76 & 3 & 0.92 & $4.98^{*}$ & 11.28 & 3 & 3.76 & $37.54 * *$ \\
\hline & Treatment & 10.76 & 1 & 10.76 & $58.35 * *$ & 6.06 & 1 & 6.06 & $60.52 * *$ \\
\hline & $\begin{array}{l}\text { Cultivar } \times \\
\text { Treatment }\end{array}$ & 1.85 & 3 & 0.62 & 3.34 & 1.14 & 3 & 1.14 & $11.41 * *$ \\
\hline & Error & 2.95 & 16 & 0.18 & & 1.60 & 16 & 0.10 & \\
\hline \multirow[t]{4}{*}{ Chl b } & Cultivar & 1.37 & 3 & 0.46 & 3.14 & 3.08 & 3 & 1.03 & $11.92 * *$ \\
\hline & Treatment & 3.77 & 1 & 3.77 & $25.98 * *$ & 4.26 & 1 & 4.26 & $49.59 * *$ \\
\hline & $\begin{array}{l}\text { Cultivar } \times \\
\text { Treatment }\end{array}$ & 0.45 & 3 & 0.15 & 1.04 & 1.84 & 3 & 0.61 & $7.14 * *$ \\
\hline & Error & 2.32 & 16 & 0.15 & & 1.38 & 16 & 0.09 & \\
\hline \multirow[t]{4}{*}{ Chl ab } & Cultivar & 7.18 & 3 & 2.39 & $4.02 *$ & 25.26 & 3 & 8.42 & $34.39 * *$ \\
\hline & Treatment & 29.24 & 1 & 29.24 & $49.05^{* *}$ & 20.48 & 1 & 20.48 & $83.65 * *$ \\
\hline & $\begin{array}{l}\text { Cultivar } \times \\
\text { Treatment }\end{array}$ & 3.13 & 3 & 1.04 & 1.75 & 9.20 & 3 & 3.07 & $12.52 * *$ \\
\hline & Error & 9.54 & 16 & 0.60 & & 3.92 & 16 & 0.24 & \\
\hline \multirow[t]{4}{*}{ Protein } & Cultivar & 0.01 & 3 & 0.00 & 0.97 & 0.05 & 3 & 0.02 & 2.37 \\
\hline & Treatment & 0.03 & 1 & 0.03 & $8.17^{*}$ & 0.60 & 1 & 0.60 & $86.46^{* *}$ \\
\hline & $\begin{array}{l}\text { Cultivar } \times \\
\text { Treatment }\end{array}$ & 0.01 & 3 & 0.00 & 0.80 & 0.13 & 3 & 0.04 & $6.01 * *$ \\
\hline & Error & 0.07 & 16 & 0.00 & & & & & \\
\hline \multirow[t]{4}{*}{ Phenol } & Cultivar & 1.23 & 3 & 0.41 & $15.32 * *$ & 0.59 & 3 & 0.20 & $14.31 * *$ \\
\hline & Treatment & 0.00 & 1 & 0.00 & 0.06 & 0.63 & 1 & 0.63 & $46.18 * *$ \\
\hline & $\begin{array}{l}\text { Cultivar } \times \\
\text { Treatment }\end{array}$ & 0.03 & 3 & 0.01 & 0.32 & 0.29 & 3 & 0.10 & $7.02 * *$ \\
\hline & Error & 0.43 & 16 & 0.03 & & 0.22 & 16 & 0.01 & \\
\hline \multirow[t]{4}{*}{ Sugar } & Cultivar & 75.31 & 3 & 25.10 & $102.72 * *$ & 1.07 & 3 & 0.36 & $4.20^{*}$ \\
\hline & Treatment & 1.86 & 1 & 1.86 & $7.60 *$ & 5.98 & 1 & 5.98 & $70.59 * *$ \\
\hline & $\begin{array}{l}\text { Cultivar } \times \\
\text { Treatment }\end{array}$ & 0.18 & 3 & 0.06 & 0.25 & 1.82 & 3 & 0.61 & $7.17 * *$ \\
\hline & Error & 3.91 & 16 & 0.24 & & 1.36 & 16 & 0.08 & \\
\hline
\end{tabular}




\section{Figure 1}

BYDV-PAV inoculated and control plants of susceptible barley cultivar Flagship at 3 WAI.

(A) Control. (B) Virus infected.

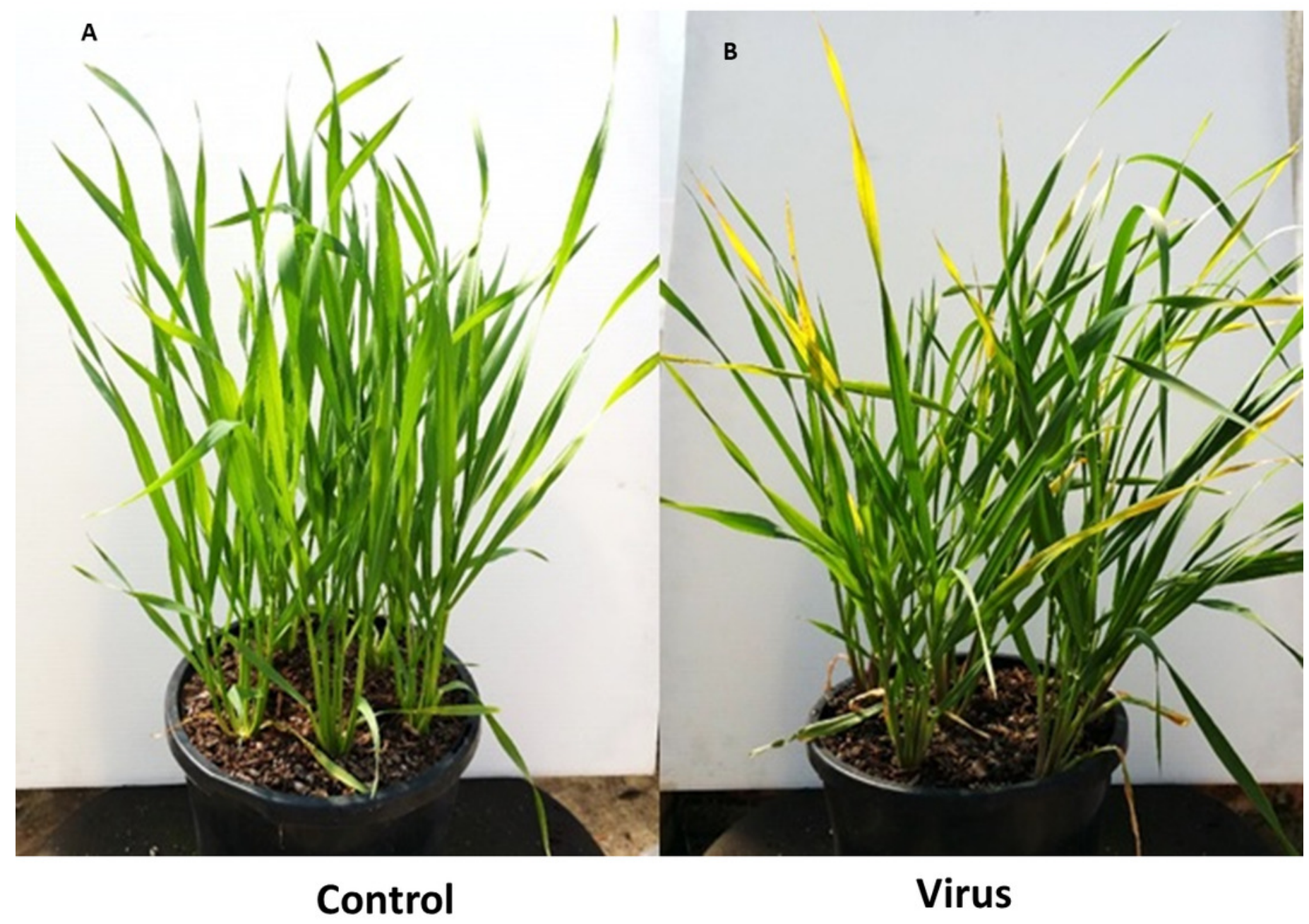




\section{Figure 2}

BYDV-PAV inoculated and control plants of susceptible wheat cultivar Revenue 6 WAI.

(A) Control. (B) Virus infected.

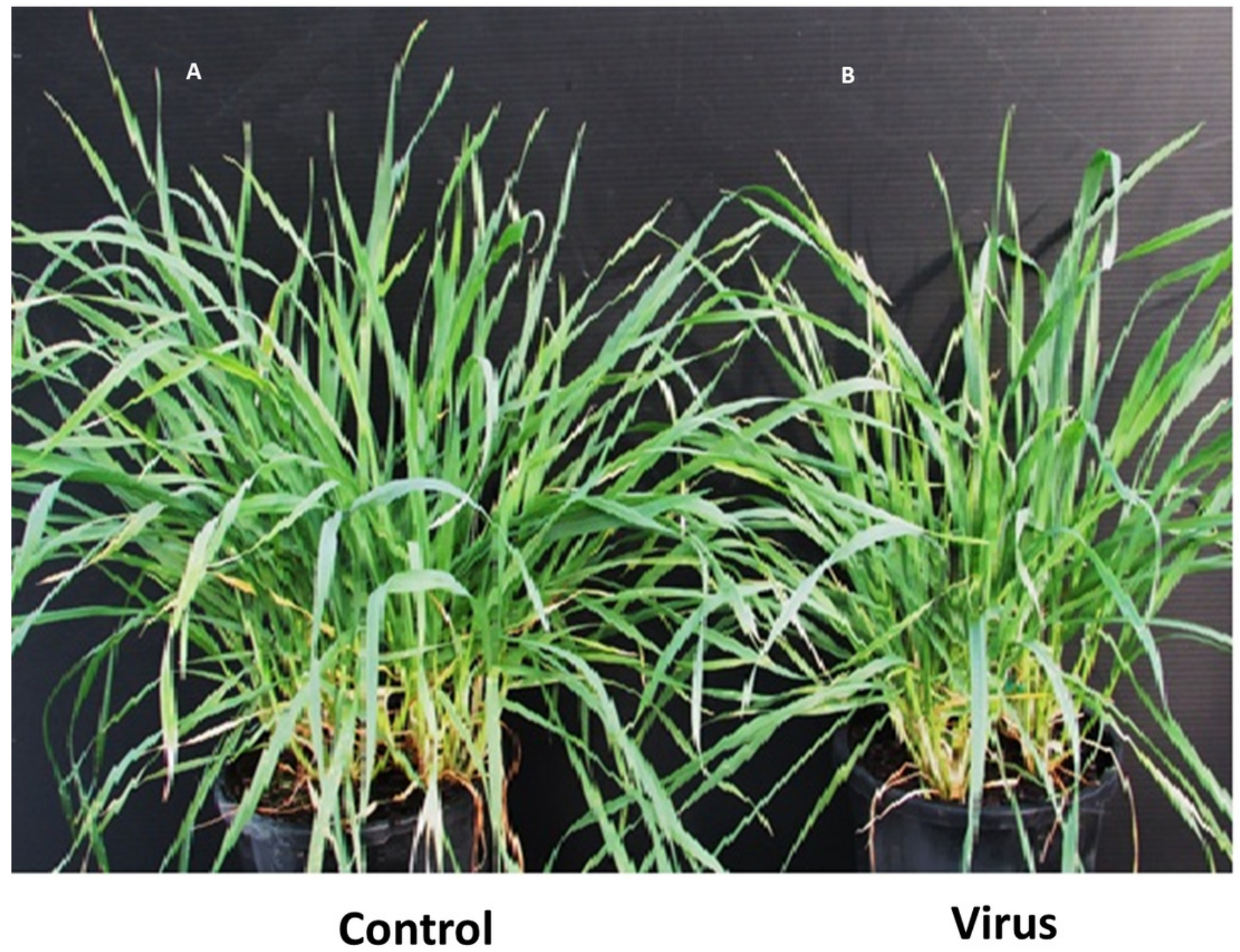


Figure 3

Mean virus extinction (A $405 \mathrm{~nm}$ ) assessed in leaf extracts of BYDV-PAV inoculated and control plants of wheat (W) and barley (B) cultivars at 6 WAl.

Mean \pm SE $(n=9)$.

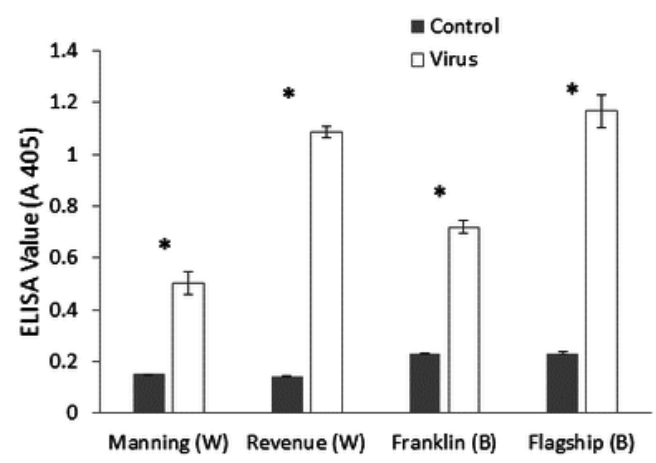


Figure 4

Root appearance $(A, B, C, D)$ and average root length (E) of BYDV-PAV inoculated and control plants of wheat (W) and barley (B) cultivars at 3 WAl.

Mean \pm SE $(n=5)$

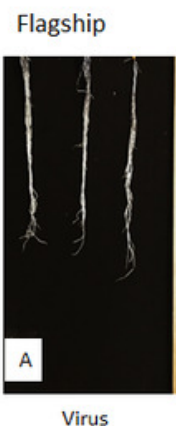

Virus

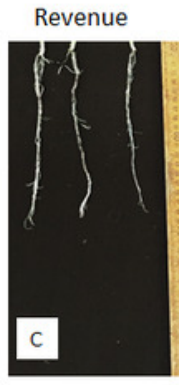

Virus
Franklin

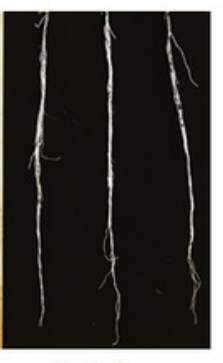

Control

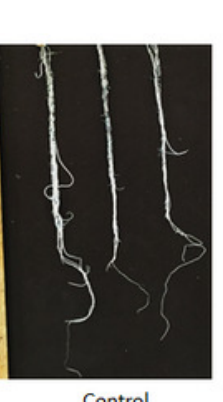

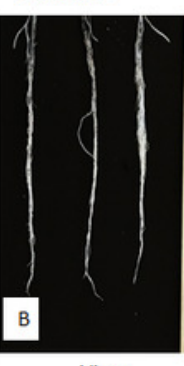

Virus

Manning

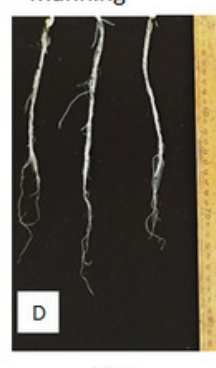

Virus

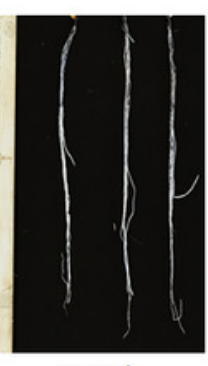

Control

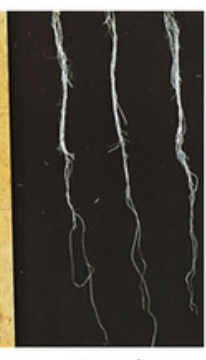

Control

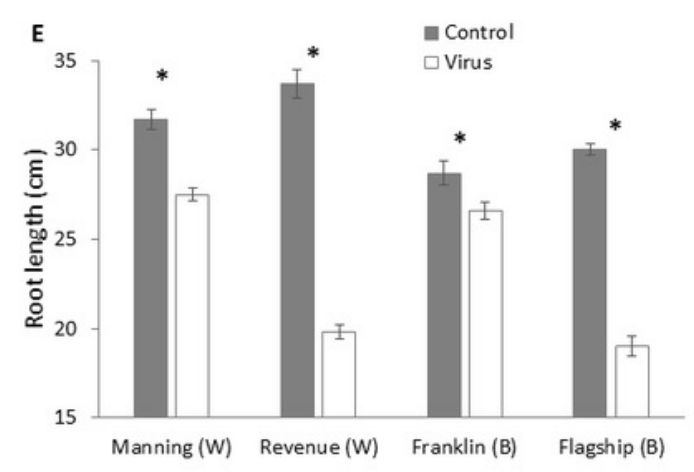


Figure 5

Average content $(\mathrm{mg} / \mathrm{g})$ of chlorophyll $\mathrm{a}$, chlorophyll $\mathrm{b}$, and total chlorophyll of BYDVPAV inoculated and control plants of wheat $(W)$ and barley $(B)$ cultivars at 3 WAI $(A, B, C)$ and 6 WAI $(D, E, F)$.

Mean \pm SE $(n=6)$
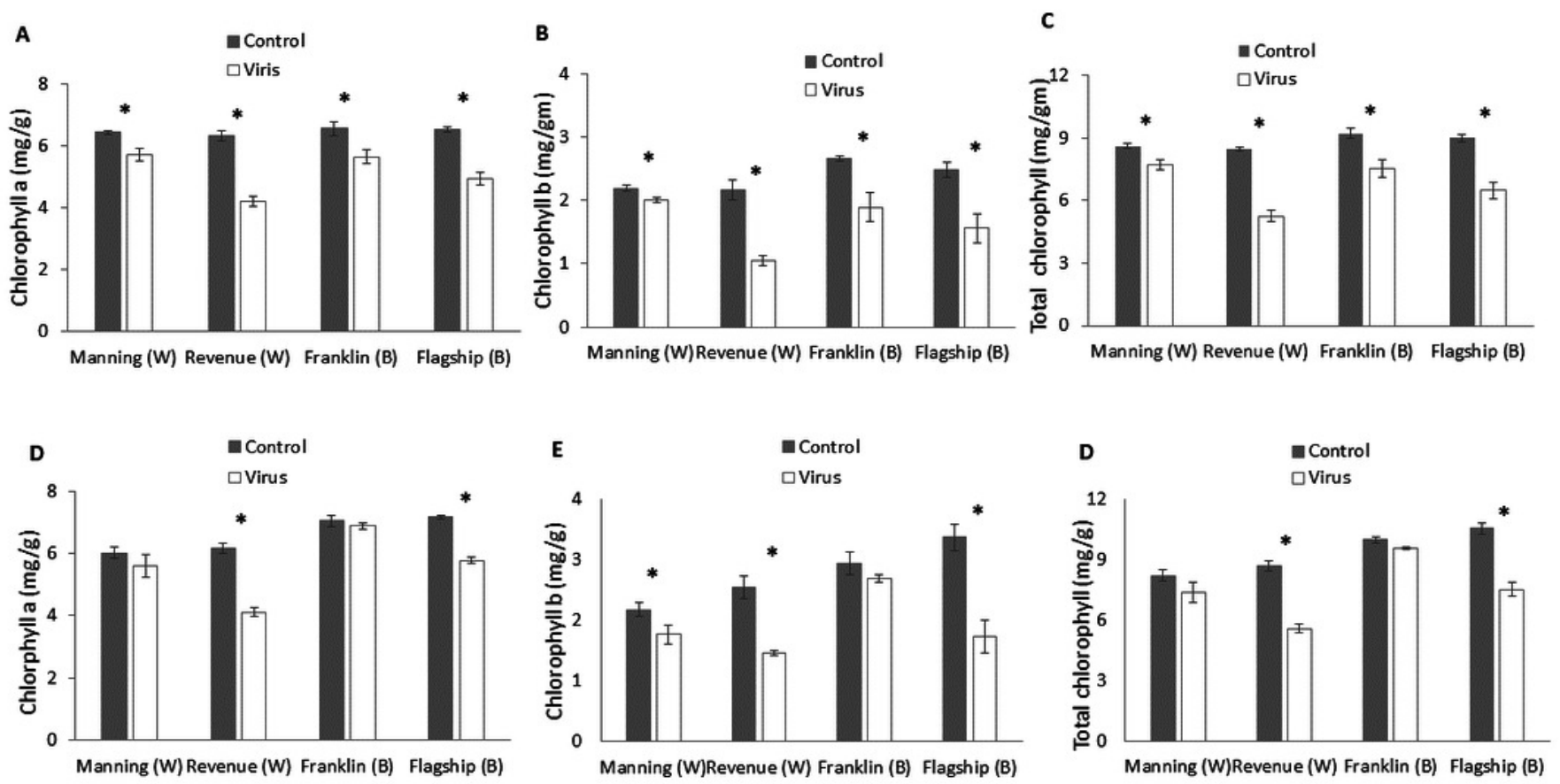
Figure 6

Average content ( $\mathrm{mg} / \mathrm{g}$ leaf fresh weight) of total protein of BYDV-PAV inoculated and control plants of wheat (W) and barley (B) cultivars at 3 WAI (A) and 6 WAI (B).

Mean $\pm S E(n=6)$
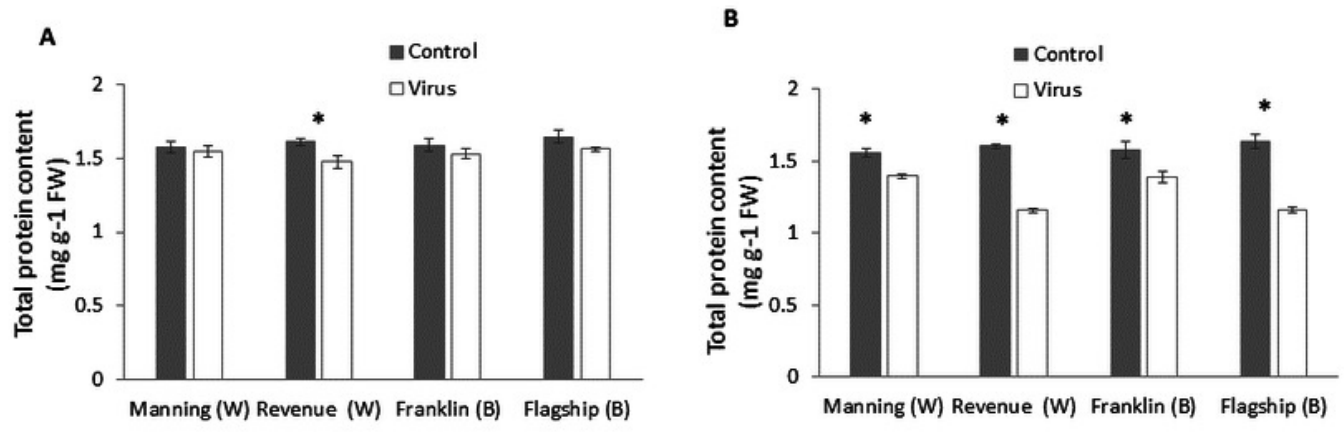
Figure 7

Average content ( $\mathrm{mg} / \mathrm{g}$ leaf fresh weight) of total phenol of BYDV-PAV inoculated and control plants of wheat (W) and barley (B) cultivars at 3 WAI (A) and 6 WAI (B).

Mean $\pm S E(n=6)$
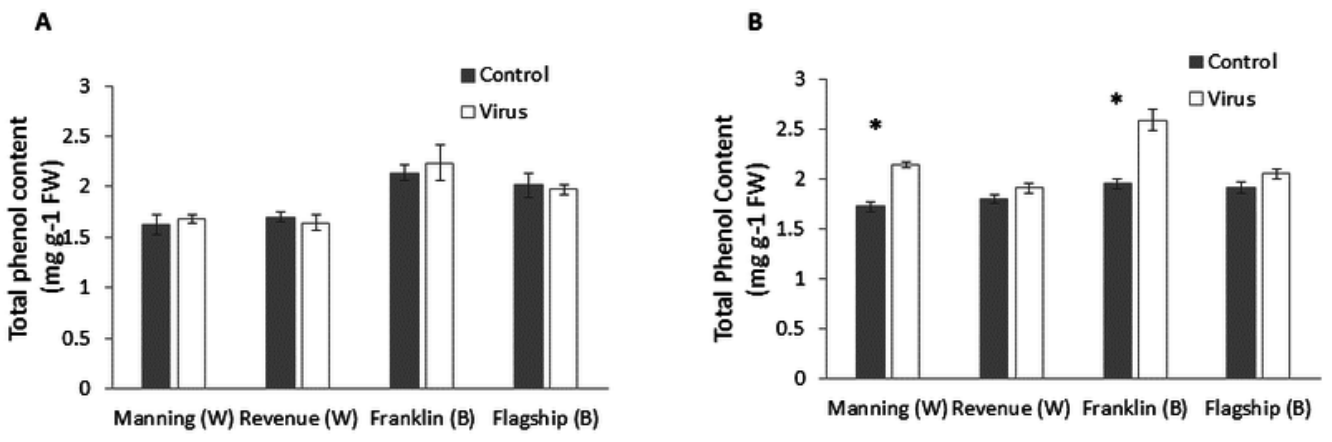
Figure 8

Average content of ( $\mathrm{mg} / \mathrm{g}$ leaf fresh weight) reducing sugar of BYDV-PAV inoculated and control plants of wheat (W) and barley (B) cultivars at 3 WAI (A) and 6 WAI (B).

Mean $\pm S E(n=6)$.

A

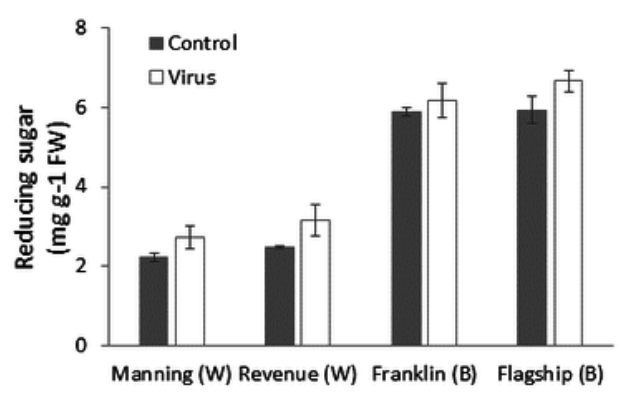

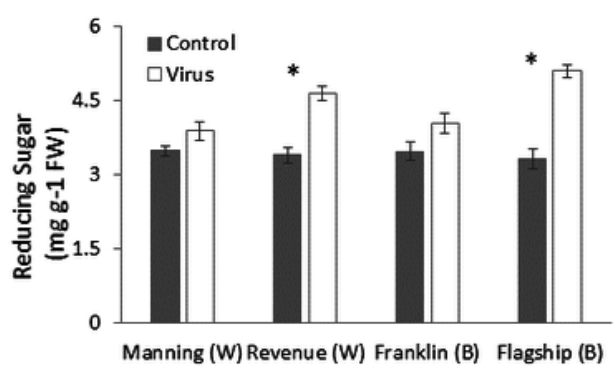


Figure 9

Average shoot fresh weight ( $g$ ) (A) and relative dry matter (B) of BYDV-PAV inoculated and control plants of wheat (W) and barley (B) cultivars at 6 WAI.

Mean \pm SE $(n=9)$.

A

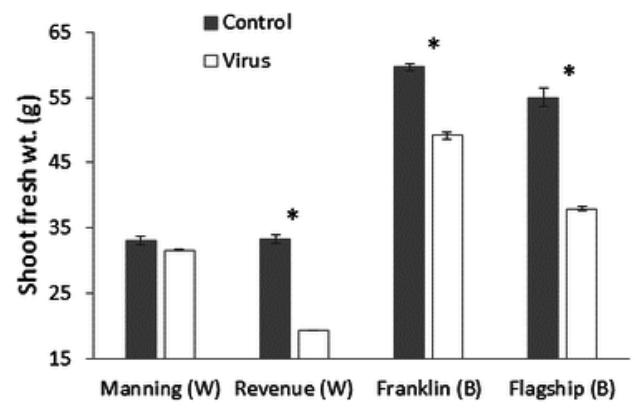

B

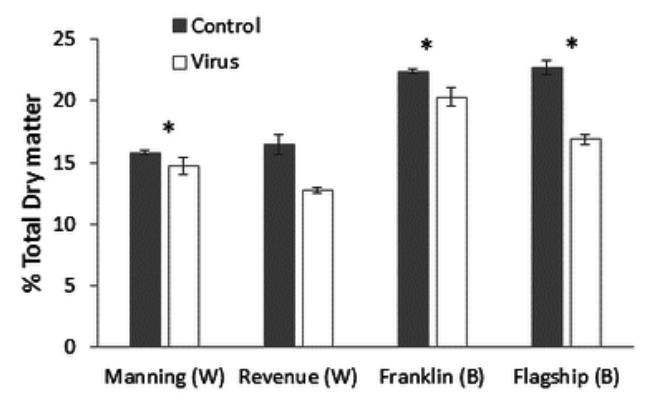




\section{Figure 10}

Transverse sections of foliar vascular bundles of susceptible (Flagship) and resistant (Franklin) barley cultivars

A, C from control plants and B, D from BYDV-PAV inoculated plants. Details are SE=sieve elements, $\mathrm{CC}=$ companion cell, NSE = necrotic sieve elements, LISE = little infected sieve elements. Mean $\pm \operatorname{SE}(n=3)$.
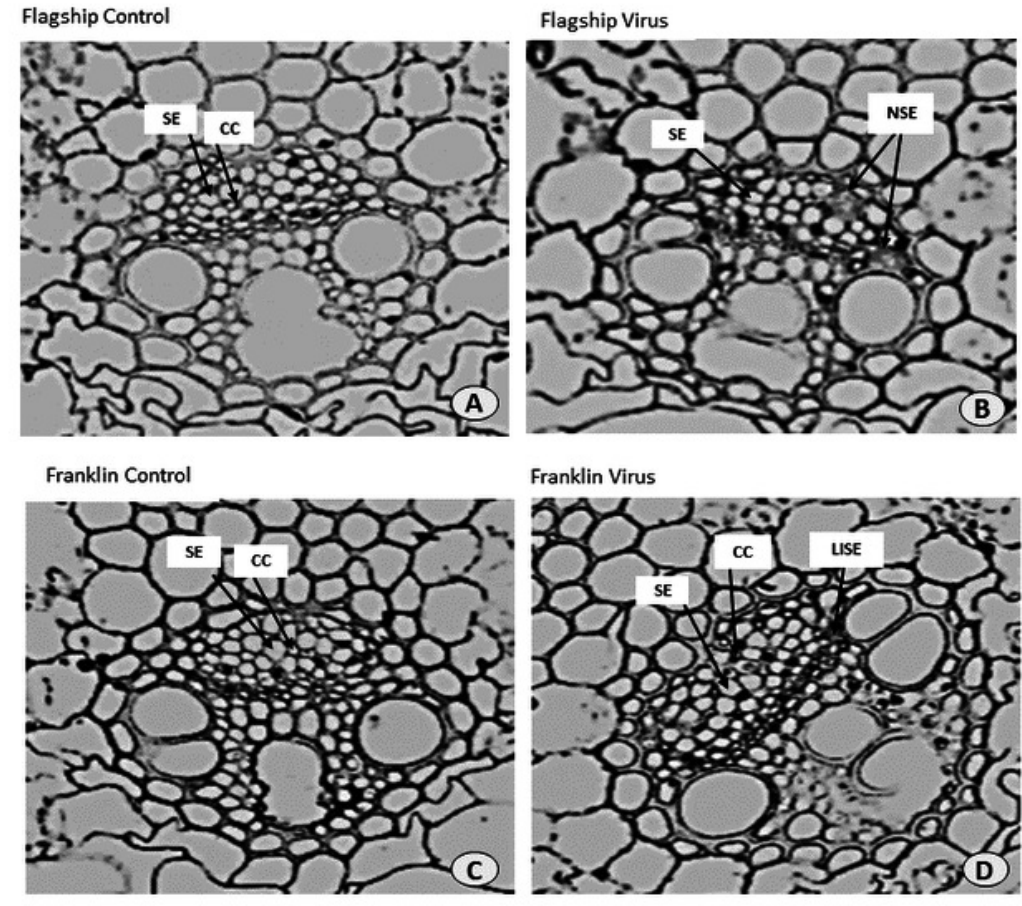

Franklin Virus

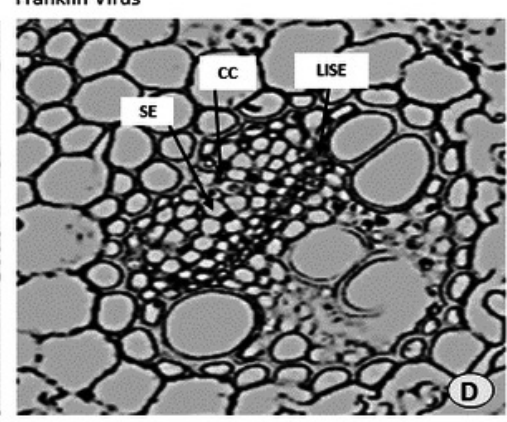


Figure 11

Transverse sections of foliar vascular bundles of susceptible (Revenue) and resistant (Manning) wheat cultivars

A, C from control plants and B, D from BYDV-PAV inoculated plants. Details are $S E=s i e v e$ elements, $\mathrm{CC}=$ companion cell, ISE= infected sieve elements, IPP= infected phloem parenchyma. Mean $\pm S E(n=3)$.
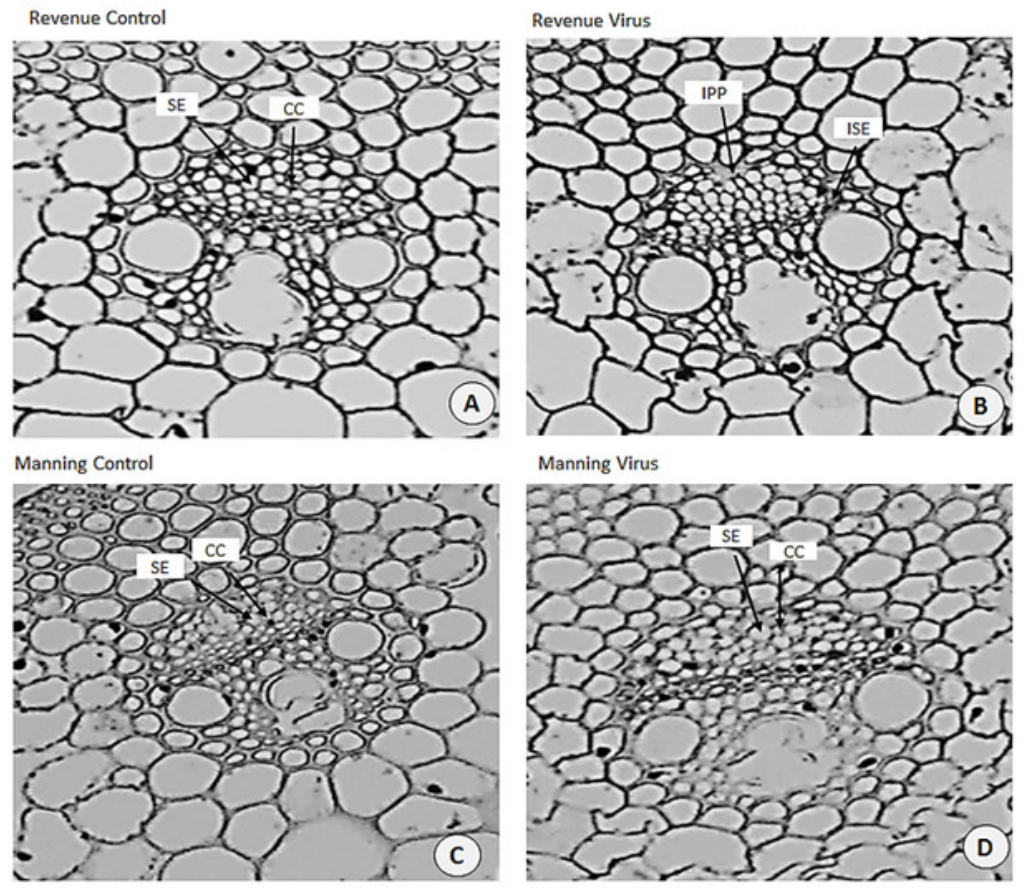